\title{
PRODUKTIVITAS TANAMAN LEGUMINOSA (Centrocema pubescens DAN Clitoria ternatea) YANG DIPUPUK DENGAN PUPUK BIO SLURRY
}

\author{
WITARIADI N. M. DAN N.N. CANDRAASIH K. \\ Fakultas Peternakan,Universitas Udayanan \\ Email: witarimade@yahoo.com
}

\begin{abstract}
ABSTRAK
Penelitian untuk mengetahui produktivitas tanaman leguminosa yang dipupuk dengan pupuk bio slurry telah dilaksanakan. Rancangan yang digunakan adalah rancangan acak lengkap (RAL) pola faktorial dengan dua faktor. Faktor pertama adalah jenis tanaman leguminosa yaitu Centrocema pubescens dan Clitoria ternatea, faktor kedua adalah dosis pupuk bio-slurry yaitu tanpa pemberian pupuk sebagai kontrol; pemberian pupuk bio slurry 10 ton/ ha; pemberian pupuk bio slurry 20 ton/ha; pemberian pupuk bio slurry 30 ton/ha. Variabel yang diamati yaitu variabel pertumbuhan (tinggi tanaman, jumlah batang, dan jumlah daun); variabel produksi (berat kering daun, berat kering batang, berat kering akar, dan berat kering total hijauan); dan variabel karakteristik tumbuh (luas daun, nisbah berat kering daun dengan berat kering batang, dan nisbah berat kering total hijauan dengan berat kering akar). Hasil penelitian menunjukkan bahwa pemberian pupuk bio slurry mampu meningkatkan produktivitas tanaman leguminosa. Perbedaan perlakuan pupuk bio slurry (10-30 ton/ha), secara nyata $(\mathrm{P}<0,05)$ meningkatkan jumlah anakan, jumlah daun, berat kering total hijauan, berat kering daun, berat kering batang, berat kering akar, luas daun, nisbah berat kering total hijauan dengan akar, dan nisbah daun dengan batang. Disimpulkan bahwa, hasil terbaik didapatkan pada jenis leguminosa Clitoria ternatea dan dosis pupuk bio slurry dosis 30 ton/ha.
\end{abstract}

Kata kunci: pertumbuhan, produksi, Centrocema pubescens, Clitoria ternatea, bio-slurry

\section{PRODUCTIVITY OF FORAGE LEGUME (Centrocema pubescens DAN Clitoria ternatea) FERTILIZED WITH BIO SLURRY}

\begin{abstract}
This study aims at determining the productivity of legume fertilized with bio slurry. The study was conducted by using a complete randomized design (CRD) with two factors as factorial design. The first factor is the type of legume plants, namely Centrocema pubescen and Clitoria ternatea. The second factor is the dosage of bioslurry fertilizer such as fertilizer as control; 10 tons/ha of bioslurry fertilizer; 20 tons/ha of bioslurry fertilizer; 30 tons/ ha of bio slurry fertilizer. Variables observed were growth (plant height, number of tillers, and number of leaves); production variables (leaf dry weight, stem dry weight, root dry weight and total dry weight of forage); and growth characteristics (leaf area, leaf dry weight ratio of dry weight rod, and ratio of the total dry weight of forage with root dry weight). The results showed that the bio-slurry fertilizer increase productivity and legume plants (Centrocema pubescen and Clitoria ternatea). The differences of 10-30 tons/ha bioslurry treatment significantly $(\mathrm{P}<0.05)$ increase number of tillers, number of leaves, total forage dry weight, dry weight of leaf, stem dry weight, root dry weight, leaf area, ratio of total dry weight of forage with roots and leaves with the stem ratio). It can be concluded that higher productivity of legume plants species found significantly $(\mathrm{P}<0.05)$ on Clitoria ternatea with 30 tons/ha dosages of bioslurry fertilizer as the best result.
\end{abstract}

Keywords: growth, production, Centrocema pubescens, Clitoria ternatea, bio slurry

\section{PENDAHULUAN}

Keberhasilan suatu usaha peternakan sangat tergantung dari ketersediaan pakan, dimana pakan utama ternak ruminansia berasal dari hijauan. Pendapat ini didukung oleh Soetarno (2003) bahwa hijauan merupakan pakan utama untuk ternak ruminansia dan hijauan sebagai pakan bagi ternak dapat berasal dari rumput, daun-daunan, dan sisa-sisa panen berupa jerami. Hijauan mengandung hampir semua 
zat makanan yang dibutuhkan oleh ternak ruminansia baik untuk mempertahankan hidup, pertumbuhan, produksi, maupun reproduksinya (Winarsih, 2002). Tata (1995) menyatakan bahwa sumber pakan bagi ternak ruminansia hampir $70 \%$ dari jumlah yang diberikan terdiri dari hijauan. Tingginya kebutuhan akan sumber hujauan, maka perlu adanya perhatian dalam penyediaannya baik dari segi kuantitas maupun kualitas.

Leguminosa adalah alternatif dalam pengadaan hijauan makanan ternak dimana jenis hijauan dari leguminosa sangat baik untuk pertumbuhan ternak ruminansia. Kuantitas maupun kualitas tanaman leguminosa dapat menyediakan pakan sepanjang tahun dengan kandungan nutrisi yang cukup tinggi untuk pertumbuhan ternak. Dalam menyediakan hijauan biasanya terdapat kesulitan yang disebabkan oleh keterbatasan lahan dan semakin menurunnya kesuburan tanah, terlebih jika sistem penyediaan hijauan makanan ternak dilakukan secara cut and carry, karena pada umumnya dalam sistem ini tidak ada pengembalian unsur hara tanah sebagai pengganti hara yang diambil oleh hijauan yang dipanen. Faktor yang perlu diperhatikan dalam usaha peningkatan produksi dan mutu hijauan antara lain tersedianya unsur hara yang diperlukan tanaman di dalam tanah. Untuk itu perlu dilakukan usaha pemupukan, terlebih tanah yang digunakan untuk penanaman hijauan makanan ternak umumnya adalah tanah non produktif atau kekurangan unsur hara, sedangkan tanah yang produktif lebih cenderung digunakan untuk tanaman pangan. Melihat kondisi seperti ini maka perlu dilakukan peningkatan kesuburan tanah baik fisik, kimia, maupun biologi melalui pemupukan dengan menggunakan pupuk organik.

Pupuk organik adalah pupuk yang sebagian atau seluruhnya terdiri atas bahan organik yang berasal dari tanaman atau hewan, dapat berbentuk padat atau cair yang digunakan mensuplai bahan organik untuk memperbaiki sifat fisik, kimia, dan biologi tanah (Suriadikarta dan Simanungkalit, 2006). Sumber pupuk organik dapat berupa kompos, pupuk hijau, pupuk kandang, sisa panen, limbah ternak, limbah industri yang menggunakan bahan pertanian, limbah kota dan limbah biogas (slurry). Slurry berpotensi sebagai pupuk organik. Untuk meningkatkan kualitas pupuk slurry dan lebih cepat tersedia bagi tanah dan tanaman maka pupuk slurry diberikan perlakuan melalui fermentasi. Tujuan fermentasi adalah untuk mempercepat proses perombakan bahan organik sehingga lebih cepat tersedia bagi tanah dan lebih mudah diserap oleh tumbuhan. Bio slurry adalah produk akhir pengolahan limbah berbahan kotoran sapi yang berbentuk padat dan cair yang sangat bermanfaat sebagai sumber nutrisi untuk tanaman dan mengandung mikroba pro-biotik yang bermanfaat untuk meningkatkan kesuburan lahan pertanian sehingga diharapkan akan berdampak pada peningkatan kualitas dan kuantitas hasil panen. Komposisi slurry setelah fermentasi (bio slurry) adalah air 70-80\% dan zat kering 20-30\%, jika diuraikan lagi zat kering tersebut mengandung bahan organik 18-27\%. Kandungan lain yang terdapat dalam bio slurry yaitu asam amino, asam lemak, asam organik, asam humat, vitamin B-12, hormon auksin, sitokinin, antibiotik, dan nutrisi mikro yaitu besi $(\mathrm{Fe})$, tembaga $(\mathrm{Cu})$, zink $(\mathrm{Zn})$, mangan (Mn), dan molybdenum (Mo) (Internasional Training Workshop, 2010). Arnawa (2014) bahwa penggunaan limbah biogas dengan dosis 10-30 ton/ ha memberikan pengaruh yang sama terhadap pertumbuhan dan produksi pada rumput benggala (Panicum maximum cv. Trichoglume).

Berdasarkan informasi di atas bahwa pemanfaatan limbah biogas (slurry) pada tanaman leguminosa sangat terbatas maka penelitian ini dirasa sangat perlu dilaksanakan untuk mengetahui produktivitas tanaman leguminosa yang diberikan pupuk bio slury.

\section{MATERI DAN METODE}

\section{Tempat Penelitian}

Penelitian dilaksanakan di rumah kaca di Desa Sading, Badung dan berlangsung selama tiga bulan. Penelitian ini terdiri dari dua bagian yaitu bagian pertama dilakukan fermentasi slurry dan bagian kedua adalah implementasi pupuk fermentasi (bio slurry) pada tanaman leguminosa (Centrocema pubescens dan Clitoria ternatea) untuk mengetahui produktivitas tanaman leguminosa.

\section{Tanah dan Pupuk}

Tanah yang digunakan berasal dari lahan kosong di Desa Sading, Badung dan limbah biogas (slurry) serta bio slurry diambil dari kelompok Simantri di Desa Kelating, Kabupaten Tabanan. Tanah dan pupuk sebelum digunakan dianalisa di Laboratorium Ilmu Tanah, Fakultas Pertanian, Universitas Udayana (Tabel 1).

\section{Rancangan Percobaan}

Penelitian menggunakan rancangan acaklLengkap (RAL) pola faktorial dengan dua faktor. Faktor pertama adalah jenis tanaman leguminosa yaitu: $\mathrm{Cp}$ : leguminosa Centrosema pubescens, Ct: leguminosa Clitoria ternatea dan faktor kedua adalah dosis pupuk bio slurry: Do: tanpa pemberian pupuk (kontrol); D1: pemberian pupuk bio slurry 10 ton/ha (20 g/pot); D2:pemberian pupuk bio slurry 20 ton/ha (40 g/pot); D3: pemberian pupuk bio slurry 30 ton/ha (6o g/pot). Dari kedua faktor tersebut diperoleh delapan (8) kombinasi perlakuan 
yaitu: CpDo, CpD1, CpD2, CpD3, CtDo, CtD1, CtD2 dan CtD3 dan setiap kombinasi perlakuan diulang sebanyak empat kali, sehingga terdapat 32 pot penelitian.

\section{Variabel Yang Diamati}

Variabel yang diamati pada penelitian ini meliputi: tinggi tanaman (cm); jumlah batang (batang); jumlah daun (helai); luas daun per pot (cm); berat kering daun (g); berat kering batang (g); nisbah berat kering daun dengan batang; berat kering tajuk (g); berat kering akar (g); dan nisbah berat kering tajuk dengan akar.

\section{Analisa Data}

Data yang diperoleh dianalisis dengan analisis sidik ragam, apabila diantara nilai rata-rata perlakuan menunjukkan perbedaan yang nyata, maka analisis dilanjutkan dengan uji jarak berganda Duncan (Program SPSS).

Tabel 1. Hasil analisa tanah, slurry dan bio slurry

\begin{tabular}{|c|c|c|c|}
\hline Uraian & Tanah & Slurry & Bio Slurry \\
\hline $\mathrm{pH}(1: 2,5) \mathrm{H}_{2} \mathrm{O}$ & 6,67 & 6,70 & 6,72 \\
\hline $\mathrm{DHL}$ (mmhos/cm) & 1,57 & 2,01 & 3,45 \\
\hline C Organik (\%) & 3,12 & 18,65 & 22,48 \\
\hline N Total (\%) & 0,11 & 0,19 & 1,37 \\
\hline P Tersedia (ppm) & 531,88 & 311,25 & 732,45 \\
\hline KTK (me/100g) & 23,93 & - & - \\
\hline \multicolumn{4}{|l|}{ Kadar Air : } \\
\hline KU (\%) & 6,83 & 19,69 & 28,22 \\
\hline KL (\%) & 23,14 & - & - \\
\hline \multicolumn{4}{|l|}{ Tekstur: } \\
\hline Pasir (\%) & 40,22 & - & - \\
\hline Debu (\%) & 51,14 & - & - \\
\hline Liat (\%) & 8,65 & - & - \\
\hline \multicolumn{4}{|l|}{ Keterangan : } \\
\hline DHL: Daya Hantar Listrik & C Organik & \multicolumn{2}{|c|}{ Nalkley \& Black } \\
\hline KU : Kering Udara & N Total & \multicolumn{2}{|c|}{ Metode Kjelhall } \\
\hline KL : Kapasitas Lapang & $\mathrm{KU}$ dan $\mathrm{KL}$ & \multicolumn{2}{|c|}{ Metode Graviment } \\
\hline P : Posfor & & \multicolumn{2}{|c|}{ Metode bray-1 } \\
\hline $\mathrm{N}$ : Nitrogen & Tekstur & \multicolumn{2}{|c|}{ Metode Pipet } \\
\hline
\end{tabular}

\section{HASIL DAN PEMBAHASAN}

Hasil penelitian menunjukkan bahwa terjadi interaksi antara dosis pupuk bio slurry terhadap pertumbuhan dan produktivitas tanaman leguminosa (Centrocema pubescens dan Clitoria ternatea). Hal ini mengindikasikan bahwa antara faktor dosis pupuk bio slurry dan jenis tanaman leguminosa dapat secara bersama atau sendiri-sendiri dalam mempengaruhi pertumbuhan dan produksi tanaman leguminosa (Centrocema pubescens dan Clitoria ternatea).

Pertambahan tinggi tanaman tertinggi terdapat pada perlakuan Do (kontrol) dan berbeda tidak nyata $(\mathrm{P}>0,05)$ dengan D2 dan D3 (Tabel 2). Hal ini disebabkan pada perlakuaan Do (tanpa pupuk) unsur hara yang tersedia hanya digunakan oleh tanaman leguminosa untuk pertumbuhan ke atas (vertikal) dan belum mampu untuk melakukan pertumbuhan ke samping (horisontal), tetapi pada tanaman yang diberi pupuk bio slurry disamping melakukan pertumbuhan ke atas juga melakukan pertumbuhan ke samping untuk perbanyakan cabang.

Pada perlakuan pemberian pupuk bio slurry walaupun tidak nyata lebih rendah dengan Do pada variabel tinggi tanaman, tetapi tanaman leguminosa mampu memanfaatkan unsur hara yang tersedia untuk pertumbuhan anakan dan memperbanyak daun. Terlihat pada variabel jumlah anakan dan jumlah daun nyata lebih tinggi dibandingkan dengan perlakuan Do. Hal ini menunjukkan bahwa pupuk bio slurry yang sudah mengalami proses penguraian melalui proses fermentasi dapat menyediakan unsur hara yang langsung dimanfaatkan oleh tanaman untuk pertumbuhan. Semakin meningkat dosis pupuk bio slurry yang diberikan pada tanaman leguminosa, maka makin tinggi tingkat pertumbuhan tanaman akibat semakin meningkat ketersediaan unsur hara bagi tanaman (Kerley et al.,1996 dan Widjajanto at al.,2001). Jumlah anakan dan jumlah daun tanaman leguminosa yang diberi pupuk bio slurry menunjukkan hasil yang nyata lebih tinggi dibandingkan dengan Do. Hal ini karena kandungan nitrogen (N) pada pupuk bio slurry lebih tinggi (Tabel 1), dimana nitrogen merupakan unsur hara utama bagi pertumbuhan tanaman yang pada umumnya sangat diperlukan untuk pembentukan dan pertumbuhan bagian-bagian vegetatif tanaman seperti daun, batang dan akar ( Sutedjo, 2002).

Berat kering tajuk tanaman leguminosa yang diberi pupuk bio slurry nyata $(\mathrm{P}<0,05)$ lebih tinggi dibandingkan dengan Do (Tabel 3). Hal ini karena tanaman leguminosa yang diberi pupuk bio slurry mempunyai berat kering batang dan berat kering daun yang lebih tinggi dan luas daun yang lebih lebar. Luas daun yang lebih lebar memungkinkan tanaman untuk meningkatkan proses fotosintesis. Kapasitas fotosintesis yang berlangsung lebih tinggi, sehingga hasil fotosintesis yang dihasilkan berupa karbohidrat dan protein memberikan hasil yang maksimal. Hasil analisa terhadap komposisi kimia hijauan pakan yang dipupuk dengan bio slurry (30 ton/ha) pada tanaman Clitoria ternatea memberikan hasil tertinggi yaitu: protein (22,075\%); kadar air (8,388\%); dan kadar abu $(8,975 \%)$. Hasil dari proses fotosintesis akan disebarkan ke seluruh bagian tanaman, sehingga berat kering tanaman menjadi meningkat. Karbohidrat dan protein merupakan komponen penyusun berat kering tanaman. Budiana (1993) menyatakan bahwa semakin banyak kandungan karbohidrat dan protein dalam tanaman maka berat kering tanaman itu semakin tinggi.

Tingginya luas daun tanaman leguminosa yang diberi 
Tabel 2. Pengaruh dosis pupuk bio slurry terhadap pertumbuhan tanaman leguminosa

\begin{tabular}{|c|c|c|c|c|c|c|}
\hline \multirow[t]{2}{*}{ Tinggi Tanaman } & \multirow[t]{2}{*}{ Jenis Legum } & \multicolumn{5}{|c|}{ Dosis Pupuk Bio Slurry } \\
\hline & & Do & D1 & D2 & $\mathrm{D}^{2}$ & Rataan \\
\hline & & & & $\ldots . . . \mathrm{cm} \ldots \ldots \ldots . . . .$. & & \\
\hline & $\mathrm{Cp}{ }^{3}$ & $204,57^{1}$ & 182,60 & 182,65 & 206,25 & $194,01^{\mathrm{a}}$ \\
\hline & $\mathrm{Ct}$ & 204,22 & 178,50 & 196,25 & 198,80 & $194,44^{\mathrm{a}}$ \\
\hline & Rataan & $204,40^{A}$ & $180,55^{\mathrm{B}}$ & $189,45^{A B}$ & $202,52^{A}$ & \\
\hline \multirow[t]{6}{*}{ Jumlah Anakan } & Jenis Legum & & & Pupuk Bio S & & \\
\hline & & DO & D1 & D2 & $\mathrm{D}^{2}{ }^{2}$ & Rataan \\
\hline & & & & Batang....... & & \\
\hline & $C p^{3}$ & $11,75^{1}$ & 23,25 & 17,75 & 23,75 & $19,12^{b}$ \\
\hline & $\mathrm{Ct}$ & 16,25 & 25,25 & 20,25 & 26,75 & $22,12^{\mathrm{a}}$ \\
\hline & Rataan & $14,00^{C}$ & $24,25^{\mathrm{A}}$ & $19,00^{\mathrm{B}}$ & $25,25^{A}$ & \\
\hline \multirow[t]{6}{*}{ Jumlah Daun } & Jenis Legum & & & Pupuk Bio S & & \\
\hline & & DO & D1 & D2 & $\mathrm{D}^{2}{ }^{2}$ & Rataan \\
\hline & & & & ...Helai......... & & \\
\hline & $\mathrm{Cp}{ }^{3}$ & $57,00^{1}$ & 90,75 & 96,75 & 118,25 & $90,68^{b}$ \\
\hline & $\mathrm{Ct}$ & 74,75 & 91,50 & 106,50 & 128,50 & $100,31^{\mathrm{a}}$ \\
\hline & Rataan & $65,87^{C}$ & $91,12^{\mathrm{B}}$ & $101,62^{B}$ & $123,37^{\mathrm{A}}$ & \\
\hline
\end{tabular}

Keterangan:

Nilai dengan huruf kapital berbeda pada kolom atau baris yang sama berbeda nyata $(P<0,05)$ dan nilai dengan huruf kecil yang sama berbeda tidak nyata $(P>0,05)$

D0 : Tanpa pemberian pupuk (control), D1 : Pemberian pupuk bio slurry 10 ton/ha, D2 : Pemberian pupuk bio slurry 20 ton/ha ,dan D3: Pemberian pupuk bio s/urry 30 ton/ha

$\mathrm{Cp}$ : Centrocema pubescen, $\mathrm{Ct}$ : Clitoria ternatea

Tabel 3. Pengaruh dosis pupuk bio slurry terhadap produksi tanaman leguminosa

\begin{tabular}{|c|c|c|c|c|c|c|}
\hline Berat Kering Tajuk & Jenis Legum & & & Dosis Pupuk Bio Slurry & & \\
\hline & & DO & D1 & $\mathrm{D} 2$ & D3 & Rataan \\
\hline & & & & 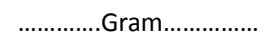 & & \\
\hline & $\mathrm{Cp}{ }^{3}$ & $74,50^{1}$ & 78,50 & 82,25 & 86,75 & $86,50^{\mathrm{a}}$ \\
\hline & $\mathrm{Ct}$ & 77,25 & 80,00 & 85,00 & 92,50 & $83,68^{b}$ \\
\hline & Rataan & $75,87^{C}$ & $79,25^{\mathrm{BC}}$ & $83,62^{\mathrm{B}}$ & $89,62^{A}$ & \\
\hline \multirow[t]{6}{*}{ Berat Kering Batang } & Jenis Legum & & & Dosis Pupuk Bio Slurry & & \\
\hline & & DO & D1 & $\mathrm{D} 2$ & D3 & Rataan \\
\hline & & & & 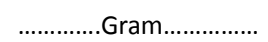 & & \\
\hline & $C p^{3}$ & $42,50^{1}$ & 40,50 & 43,00 & 44,25 & $42,56^{b}$ \\
\hline & $\mathrm{Ct}$ & 41,25 & 39,00 & 44,75 & 49,00 & $43,50^{\mathrm{a}}$ \\
\hline & Rataan & $41,87^{\mathrm{BC}}$ & $39,75^{C}$ & $43,87^{B}$ & $46,62^{A}$ & \\
\hline \multirow[t]{6}{*}{ Berat Kering Daun } & Jenis Legum & & & Dosis Pupuk Bio Slurry & & \\
\hline & & DO & D1 & D2 & D3 & Rataan \\
\hline & & & & 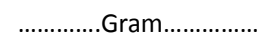 & & \\
\hline & $\mathrm{Cp}{ }^{3}$ & $32,00^{1}$ & 38,00 & 39,25 & 42,50 & $37,93^{a}$ \\
\hline & $\mathrm{Ct}$ & 36,00 & 41,00 & 40,25 & 43,50 & $40,18^{a}$ \\
\hline & Rataan & $65,87^{C}$ & $91,12^{\mathrm{B}}$ & $101,62^{\mathrm{B}}$ & $123,37^{A}$ & \\
\hline \multirow[t]{6}{*}{ Berat Kering Akar } & Jenis Legum & & & Dosis Pupuk Bio Slurry & & \\
\hline & & DO & D1 & D2 & D3 & Rataan \\
\hline & & & & $\ldots \ldots . . . . G r a m$ & & \\
\hline & $C p^{3}$ & $32,00^{1 a}$ & $26,50^{c}$ & $32,50^{\mathrm{a}}$ & $26,50^{c}$ & $29,34^{a}$ \\
\hline & $\mathrm{Ct}$ & $30,75^{\mathrm{ab}}$ & $13,25^{d}$ & $31,75^{\mathrm{a}}$ & $28,50^{\mathrm{bc}}$ & $26,06^{\mathrm{b}}$ \\
\hline & Rataan & $31,37^{A}$ & $19,87^{C}$ & $32,12^{A}$ & $27,37^{B}$ & \\
\hline
\end{tabular}

Keterangan:

Nilai dengan huruf kapital berbeda pada kolom atau baris yang sama berbeda nyata $(P<0,05)$ dan nilai dengan huruf kecil yang sama berbeda tidak nyata $(P>0,05)$

D0 : Tanpa pemberian pupuk (control), D1 : Pemberian pupuk bio slurry 10 ton/ha, D2 : Pemberian pupuk bio slurry 20 ton/ha ,dan D3: Pemberian pupuk bio s/urry 30 ton/ha

$\mathrm{Cp}$ : Centrocema pubescen, $\mathrm{Ct}$ : Clitoria ternatea

pupuk bio slurry, juga disebabkan karena tingginya kandungan C-organik dan kadar air yang terkandung pada bio slurry. Penambahan pupuk organik ke dalam tanah baik itu berupa kompos maupun pupuk kandang ternyata mengakibatkan peningkatan kadar C-organik tanah. Umar (2002) menyatakan bahwa perbedaan kandungan C-organik tanah adalah sebagai akibat dari perbedaan takaran bahan organik yang diberikan. Kadar uap air yang tinggi pada tanah mengakibatkan tanah menjadi lembab, populasi mikroorganisme yang 
Tabel 4. Pengaruh dosis pupuk bio slurry terhadap karakteristik tumbuh tanaman leguminosa

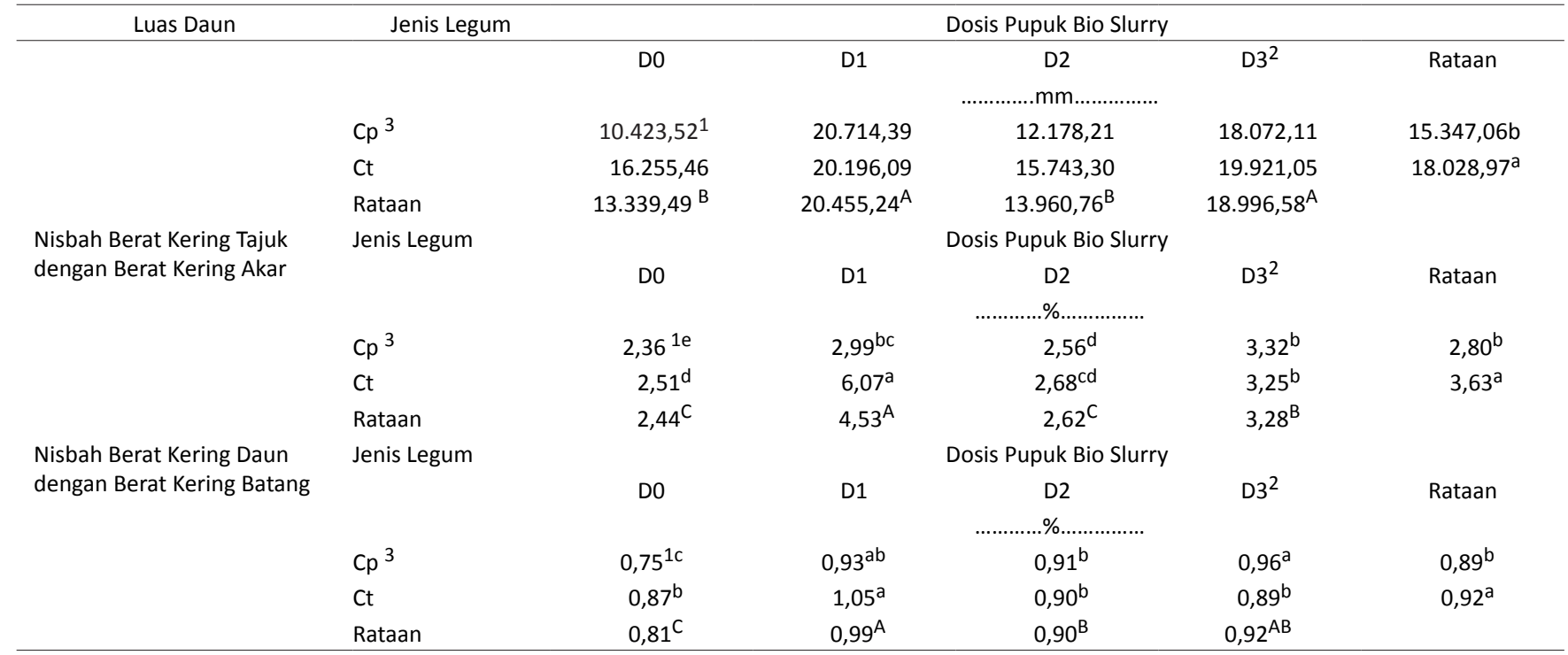

Keterangan:

Nilai dengan huruf kapital berbeda pada kolom atau baris yang sama berbeda nyata $(P<0,05)$ dan nilai dengan huruf kecil yang sama berbeda tidak nyata $(P>0,05)$

D0 : Tanpa pemberian pupuk (control), D1 : Pemberian pupuk bio slurry 10 ton/ha, D2 : Pemberian pupuk bio slurry 20 ton/ha , dan D3: Pemberian pupuk bio slurry 30 ton/ha

$\mathrm{Cp}$ : Centrocema pubescen, Ct : Clitoria ternatea

terdapat di dalam tanah dapat berkembang dengan baik dan mampu menguraikan bahan organik lebih cepat, sehingga unsur hara yang dibutuhkan oleh tanaman dapat tersedia secara sempurna. Purwowidodo (1983) bahwa tanah sebagai media pertumbuhan tanaman memberikan pengaruh bagi kelangsungan hidup tanaman, dimana kelembaban tanah memegang peranan yang sangat penting dalam proses metabolisme mikroba dan secara tidak langsung berpengaruh terhadap suplai oksigen.

Nisbah berat kering daun dengan berat kering batang tanaman leguminosa yang diberi pupuk bio slurry nyata $(\mathrm{P}<0,05)$ lebih tinggi dibandingkan dengan Do. Hal ini karena tanaman leguminosa yang dipupuk dengan bio slurry memiliki berat kering daun yang lebih tinggi (Tabel 4). Tanaman leguminosa yang memiliki kualitas yang baik, apabila memberikan nilai nisbah berat kering daun dan berat kering batang yang tinggi. Persentase berat kering daun yang lebih tinggi pada tanaman leguminosa yang dipupuk dengan bio slurry, menyebabkan kandungan karbohidrat dan proteinnya akan semakin tinggi, akan tetapi apabila tanaman leguminosa itu memiliki persentase berat kering batang yang lebih banyak dari persentase berat kering daun, maka leguminosa tersebut mempunyai kualitas yang rendah, akibat kandungan serat kasar yang terbentuk akan semakin tinggi.

Nisbah berat kering tanjuk dengan berat kering akar (top root ratio) tanaman leguminosa yang diberi pupuk bio slurry nyata $(\mathrm{P}<0,05)$ lebih tinggi dibandingkan dengan Do (Tabel 4). Tinggi rendahnya hasil dari top root ratio ini dipengaruhi oleh nilai berat kering tajuk dan berat kering akar. Dari hasil pengamatan yang dilakukan di peroleh berat kering tajuk tanaman leguminosa yang diberi pupuk bio slurry lebih tinggi dan mempunyai berat kering akar yang lebih rendah (Tabel 3). Semakin meningkat produksi total hijauan (tajuk) yang didukung dengan berat akar yang lebih rendah maka nilai top root ratio yang dihasilkan akan lebih tinggi. Nilai top root ratio yang tinggi menunjukkan produksi total hijauan yang tinggi.

Pengaruh jenis tanaman leguminosa (Centrocema pubescens dan Clitoria ternatea) dari hasil pengamatan bahwa leguminosa jenis Clitoria ternatea memberikan hasil nyata lebih tinggi dibandingakan dengan jenis Centrocema pubescens. Dilihat dari cara tumbuhnya bahwa tanaman Centrosema pubescens tumbuh dengan membelit atau menjalar, sehingga yang tumbuh hanya batang yang panjang tanpa diimbangi pertumbuhan daun, akibatnya produksi berat kering daunnya rendah (Tabel 3). Leguminosa Clitoria ternatea merupakan tumbuhan yang hidupnya merambat dan cepat tumbuh anakan dengan pertumbuhan daun yang banyak. Apabila tanaman Clitoria ternatea diberi penyangga, maka pada bagian atas akan tumbuh bergerombol dengan jumlah anakan dan daun yang banyak, akibatnya berat kering daun menjadi lebih tinggi.

\section{SIMPULAN}

Berdasarkan hasil penelitian dapat disimpulkan bahwa pemberian pupuk bio slurry dapat meningkatkan produktivitas tanaman leguminosa. Pemberian pupuk bio slurry 30 ton/ha memberikan hasil yang paling baik terhadap produktivitas tanaman leguminosa 
(Centrocema pubescesn dan Clitoria ternatea). Jenis leguminosa Clitoria ternatea memberikan respon pertumbuhan dan produksi lebih baik dibandingkan Centrocema pubescens.

\section{UCAPAN TERIMAKASIH}

Pada Kesempatan ini penulis mengucapkan banyak terimakasih kepada Rektor dan Ketua LPPM, Universitas Udayana, Denpasar atas dana yang diberikan melalui dana DIPA PNBP Universitas Udayana, sehingga penelitian dan penulisan artikel ilmiah dapat terlaksana.

\section{DAFTAR PUSTAKA}

Arnawa,I.W. 2014. Pertumbuhan dan Produksi Rumput Benggala (Panicum Maximum cv.Trchoglume) yang diberi pupuk organik dengan dosis berbeda. Skripsi. Fakultas Peternkan Universitas Udayana. Denpasar.' Budiana.1993. Produksi Tanaman Hijauan Pakan Ternak Tropis, Fakultas Peternakan Gajah Mada, Yogyakarta. Internasional Training Workshop. 2010.Training Material of Biogas Technology.Yunan Normal University Yunan,China. P 102
Purwowidodo.1983. Tehnologi Mulsa. Jakarta. Dewaruci Press.

Soetarno, T. 2003. Manajemen Budidaya Ternak Perah. Laboratorium Ternak Perah. Fakultas Peternakan Universitas Gadjah Mada. Yogyakarta.

Suriadikarta dan R.D.M. Simanungkalit. 2006. Pupuk Organik dan Pupuk Hayati. Balai Besar Penelitian dan Pengembangan Sumberdaya Lahan Pertanian. Bogor.

Sutedjo, M M. 2002. Pupuk dan Cara Penggunaan. Penerbit Rineka Cipta, Jakarta.

Tata, T. 1995. Pengaruh Jenis dan Dosis Kotoran Ternak Terhadap Produktifitas Arachis pintoi. Skripsi. Fakultas Peternakan Universitas Udayana. Denpasar.

Tim Biogas Rumah (Tim BIRU). 2012. Pedoman dan Pengguna Pengawas Pengelolaan dan Pemanfaatan Bio slurry. Kerjasama Indonesia-Belanda.Jakarta

Umar. 2002. Pengaruh Takaran Pupuk Tembaga dan Bahan Organik Terhadap Pertumbuhan dan Hasil Kedelai di Tropudult. Tesis. PS. Agronomi Ilmu-ilmu Pertanian. Universitas Gadjah Mada. Yogyakarta

Winarsih, S. 2002. Pengaruh Nisbah Pupuk Kandang dengan Pupuk Buatan terhadap Pertumbuhan dan Produksi Rumput Pennisetum purpureum cv. Mott pada Pemotongan Kedua. Skripsi. Fakultas Peternakan Universitas Udayana. Denpasar. 